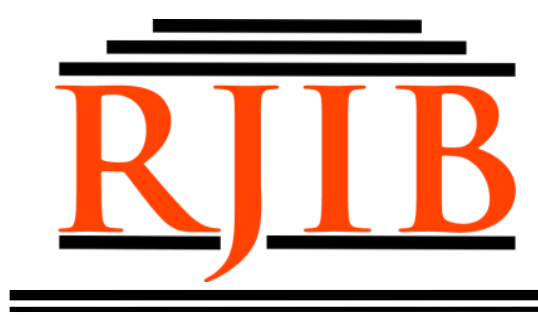

RETORIKA: Jurnal Ilmu Bahasa

Vol. 6, No. 2 October 2020, Page 98-104

P-ISSN: 2406-9019

E-ISSN: 2443-0668

Available Online at https://ejournal.warmadewa.ac.id/index.php/jret

\title{
Indonesian Interference in the Students' Writing of Recount Text at SMA Negeri 1 Toma
}

\author{
Rika Purnama Sari* and Rahmat Gaho \\ Sekolah Tinggi Keguruan dan Ilmu Pendidikan (STKIP) Nias Selatan \\ *rikapurnamamei@gmail.com
}

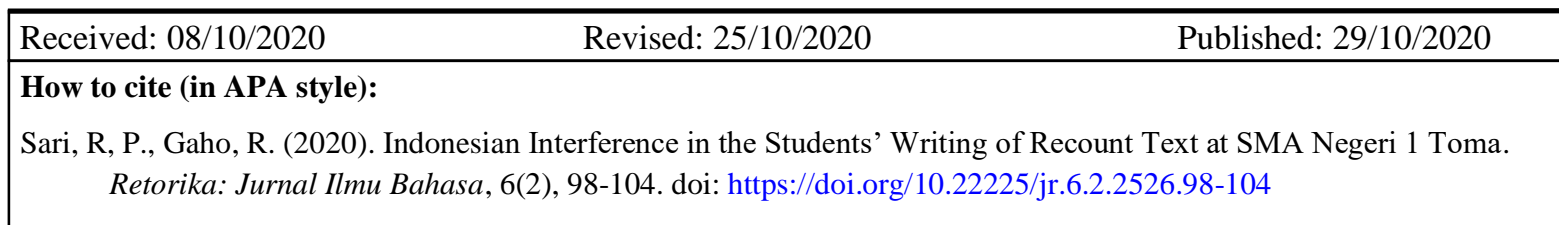

\begin{abstract}
The obejctives of this research is two-fold: to describe how Indonesian language interferes the recount text written by students of SMA Negeri 1 Toma and to identify the types of Indonesian interferences in recount texts written by Students in question. The design of this research is qualitative. Data of the research were analysed using the qualitative data analysis technique of Miles et al. (2014). The data in this research were recount text written by students of SMA Negeri 1 Toma and semistructure interview taken from the students in SMA Negeri 1 Toma. Results show Indonesian language system interfered the recount texts written by students of SMA Negeri 1 Toma in that the students adopted the way of Indonesian words, phrases, and sentences are structured. The types of Indonesian interference occur in recount text written by students of SMA Negeri 1 Toma distinguished into morphological, syntactical and semantic. Therefore, it can be concluded that students adopted the way of Indonesian words, phrases, and sentences are structured because they do not master Indonesian or L2 and English or L3 most in structuring the phrases and sentences. The teaching of English to non-English speaking people should take into account the highlights of the differences between English and Indonesian linguistic system.
\end{abstract}

Keywords: Multilingualism; Interference; Recount text

\section{INTRODUCTION}

Over half the students, particularly intermediate level, in South Nias are bilingual and a number of multilingual. A bilingual student is a student who speaks two languages. While a student who speaks more than two languages is called a multilingual student. One language is South Nias variety, another is Indonesian, and the last as language in their education, English for instance.

The language which is acquired in the first time by students in South Nias and used to communicate informally is South Nias variety or L1. It is the language spoken at home, in the market, in village churches, and at all social gatherings unless there are foreigners present (Brown, 2001). Therefore most of the students mastered South Nias variety even though it is not taught as part of the curriculum.

Indonesian is a flexible language belonging to the standard language in Indonesia. Considering the acquisition of this language, Indonesian is the second language or L2 of students in South Nias. Many recent studies described about L1 and L2, such as (Gulö, 2014), a researcher who is interested in studying the influence of L1 and L2, given the title of his study "The Influence of Nias Language to Bahasa Indonesia". The word order of VOS with VSO as a variation was one 
cause making interference in Indonesian language made by the Nias language users. For examples, möi ndra'o meneŵi influenced datang saya kemarin, alabu ia sisa andrö influenced jatuh dia di sana and tola ölau da'ö influenced bisa kamu melakukan itu (Gulö, 2014).

A multilingual student, English is a L3 of his or her. This inflected language taught in the intermediate level of students. Discussing English, there are four skills to determine the language mastery of students. They are listening, speaking, reading and writing. Writing involves the activity to arrange word per word grammatically.

In a preliminary observation, students of SMA Negeri 1 Toma were asked to write a recount text. Conceptually, recount text intended here is a kind of text which retells past events or experience. The way to arrange this text is complicated, the tense most often in the past, it makes use of time connecting event and nominal groups. Therefore, most of the students whose L1 is South Nias variety and L2 is Indonesian wrote the text incorrectly because they adopt the way Indonesian are structured, as can be seen below.

Yesterday, I arrive in Nias. I not know the language of...

Kemarin, saya tiba di Nias. Saya tidak tahu bahasa...

I live to Hilisataro. In Hilisataro I have some friend...

Saya tinggal di Hilisataro. Di Hilisataro saya mempunyai beberapa teman...

Linguistic phenomena as in sentences above related to the interference. Interference is described as adopting the way of words, phrases and sentences are structured. The interferences of language also occur in Dutch, Italian, French, and German (Swan \& Smith, 2001) are showed as follows.

The auxiliary do has no equivalent in Italian and causes conceptual difficulties.

Where he work?

Instead of where does he work?

Negatives are formed by the use of the negative particle non.

I not smoke

Instead of I do not smoke
Dutch has no do-support. Interogatives are formed by simple inversion; negatives by placing niet (not) after the verb or before the first non-finite verbal element.

What mean you?

Instead of what do you mean?

Most attributive adjectives in French are placed after the noun.

\section{A dress red}

Instead of a red dress

French uses articles, not prepositions, in common adverbials of time referring to days or parts of days.

It's very quiet here the night

Instead of It's very quiet here in night

German nouns form their plurals in various ways. Common plural endings are -en and er; beginners sometimes drop the $-\mathrm{s}$ from the plurals of English nouns that end in these letters.

\section{I have three brother}

Instead of I have three brothers.

There is a number of studies conducted before focusing on the discussion of language interference. Among them is the study conducted by Syarif (2014) revealing the factors leading Indonesian grammatical interferences on the use of English to expository writing by undergraduate students. The study revealed that the leading factors causing the undergraduate made inferences of Indonesian language to the English expository writing are linguistic and non-linguistic elements. Other study revealed that interference happened at syntactical level, at the constituent positioning within sentences (Tarukallo \& Usman, 2017). The similarity at syntactical level of two or more languages and of their systems also appears as a cause to interference occurrence (Djuanda, 2018). Mostly the interference occurs at grammatical structure when putting grammatical category of words in constructing expressions in English by Indonesian junior high school students (Agustia, 2018). Other following study also confirms that there is always interference of the first languages toward the second languages, from Indonesian to English (Budiharto, 2019). Not only at spoken language does interference happens, but it also happen in writing, one of 
the reasons is the lack of knowledge of the second language (Iman, 2020).

Initiated by the previous researches, the present research describes how Indonesian interfere the recount text written by students of SMA Negeri 1 Toma and identifies the types of Indonesian interference in recount text written by them.

\section{METHOD}

A research design is important in this research. It determines the researcher's successfulness in attaining the objectives of the research. Hence, this research was designed in qulitative research. Baker \& Ellece (2011) voiced this term refers to a number of research methods which involve nonnumerical data collection or explanation.

The data in this research are sourced from recount texts written by senior high school students of SMA Negeri 1 Toma. The data were collected through semistructured interview carried out to them. Recount text has been learned at eight classes among twelve classes in this school. 107 students were in the class during collecting the data.

In analysing the data several techniques were used. The technique used in analysing the interference of Indonesian in English recount text written by students of SMA Negeri 1 Toma was the technique qualitative data analysis of Miles et al. (2014), as narrated below:

1. Data Condensation

In this activity, researcher tried to condense the entire data gathered in the field. Focusing the data having been selected by highlighting the words, phrases and sentences was the main choice on the second activity.

\section{Data Display}

This activity let the researcher to design a group of tables of interference types in the recount texts written by students in SMA Negeri 1 Toma in which words, phrases, sentences having been highlighted are put in the table.

3. Drawing and Verifiying Conclusion

The third stream of analysis activity was drawing conclusion and verification. This activity was based on the data display activity above in which researcher built table. Then drawing and verifying conclusion was done on how Indonesian interfere recount texts written by students in which types of interference were found in the recount texts written by them.

\section{RESULTS}

The italicised words, phrases, and sentences of Indonesian are provided below taken from the students' interviewing used to describe how Indonesian interferes recount text written by students of SMA Negeri 1 Toma. Indeed the bold words, phrases, and sentences below indicated the interferences in the recount texts.

\section{a. Morphological Interference}

This type of interference is found in forming the word in a recount text.

(S1b)...around area

...keliling lingkungan

S1b

\begin{tabular}{|c|c|}
\hline Correct & Incorrect \\
\hline $\begin{array}{l}\text {...around area } \\
\text {...keliling } \\
\text { lingkungan }\end{array}$ & $\begin{array}{l}\text {...we surround } \\
\text { the area } \\
\text {...kami } \\
\text { mengelilingi } \\
\text { Lingkungan }\end{array}$ \\
\hline
\end{tabular}

This interference above occur in the root word. The Indonesian root word of keliling from mengelilingi carried out in forming word of mengelilingi in the English.

\begin{tabular}{|c|c|c|}
\hline \multicolumn{3}{|c|}{$\begin{array}{l}\text { (S6a) ...until I vomit-vomit } \\
\quad \text {...sampai saya muntah-muntah }\end{array}$} \\
\hline \multirow[t]{2}{*}{ S6a } & Incorrect & Correct \\
\hline & $\begin{array}{l}\text {...until I } \\
\text { vomit-vomit } \\
\text {...sampai saya } \\
\text { muntah- } \\
\text { muntah }\end{array}$ & $\begin{array}{l}\text {...until I } \\
\text { vomited } \\
\text {...sampai saya } \\
\text { muntah }\end{array}$ \\
\hline
\end{tabular}

It is a morphological interference in form of reduplication. The word of 'vomit-vomit' is unrecognised in English because this word is carried out from Indonesian 'muntah-muntah'. In order to avoid the reduplication, the word of 'vomit-vomit' is formed into 'vomit' without repetation.

(S13a) I'm very so happy Saya sangat amat senang

\begin{tabular}{|c|c|c|}
\hline \multirow[t]{4}{*}{$\mathrm{S} 13 \mathrm{a}$} & Incorrect & Correct \\
\hline & I'm very & I'm very happy \\
\hline & happy & Saya sangat \\
\hline & $\begin{array}{l}\text { Saya sangat } \\
\text { amat senang }\end{array}$ & senang \\
\hline
\end{tabular}


The reduplication in Indonesian sentence also occur in 'saya sangat amat bahagia'. This reduplication is necessarily to be reduplicated in Indonesian. The reduplication then is carried out into English as in 'I am very so happy'.

Moreover, morphological interference also occur in the plurality. The plural form devided into countable and uncountable noun. These following plural of countable noun are formed by carrying the form of plurality in Indonesian.

\section{(S4c) Miss brought two friend} Miss membawa dua teman

$\mathrm{S} 4 \mathrm{c}$

\begin{tabular}{|l|l|}
\hline \multicolumn{1}{|c|}{ Incorrect } & \multicolumn{1}{c|}{ Correct } \\
\hline Miss brought two & Miss brought two \\
friend & friends \\
Miss membawa & Miss membawa \\
dua teman & dua teman \\
\hline
\end{tabular}

The plurality in 'Miss brought two friend' above is carried from the form of plurality in 'Miss membawa dua teman'. The plural in countable noun, in fact, is added $-\mathrm{s}$ on the noun to indicate the reduplication of noun.

These following uncountable nouns indicate the interference of Indonesian uncountble form.

(S13a) We look very much animal...

Kami melihat sangat banyak hewan...

$\mathrm{S} 13 \mathrm{a}$

\begin{tabular}{|l|ll|}
\hline \multicolumn{2}{|c|}{ Incorrect } & \multicolumn{2}{c|}{ Correct } \\
\hline We look very & We look many \\
much animal... & animals... \\
Kami melihat & Kami r & melihat \\
sangat banyak & banyak hewan- \\
hewan... & hewan... \\
\hline
\end{tabular}

Indonesian uncountable and countable noun in 'kami melihat banyak pasir di pantai' and 'kami melihat banyak hewan di kebun binatang' are formed similarly.

\section{b. Syntactical Interference}

This type of interference found in phrases and sentences in recount text of students.

\section{Phrase}

a) Noun Phrase

A noun phrase consist of a modifier, adjective, and noun. Usually, adjectives are placed between a modifier and noun. Unfortunatelly, Indonesian has a different structure of noun phrase, the adjective is placed after noun. Therefore, the noun phrase below is carried out from Indonesian structure of noun phrase.

(S5c) Baloho beach have pool big... Pantai Baloho mempunyai kolam besar...

\begin{tabular}{|l|l|l|}
\cline { 1 - 2 } S5c & \multicolumn{1}{|c|}{ Incorrect } & \multicolumn{1}{c|}{ Correct } \\
\cline { 2 - 3 } Baloho beach & Baloho beach has \\
have pool big... & big pool... \\
Pantai Baloho & Pantai Baloho \\
mempunyai & mempunyai kolam \\
kolam besar... & besar... \\
\hline
\end{tabular}

The phrase of 'pool big' in the sentence 'Baloho beach have pool big' is carried out from Indonesian phrase of 'kolam besar'. Therefore, the phrase of 'kolam besar' in the sentence 'pantai Baloho mempunyai kolam besar' has interfered the phrase of 'pool big' in the sentence 'Baloho beach have pool big'.

\section{b) Verb Phrase}

A verb phrase consists of one or more auxiliaries in front of the verb. These following phrases carried out the structure of Indonesian phrase.

(S21b) we don't can tiket but... kami tidak dapat tiket tetapi...

$\mathrm{S} 21 \mathrm{~b}$

\begin{tabular}{|l|lr|}
\hline \multicolumn{1}{|c|}{ Incorrect } & \multicolumn{2}{c|}{ Correct } \\
\hline we don't can & we don't & get \\
tiket but... & tiket but... \\
kami tidak dapat & kami r tidak \\
tiket tetapi... & dapat r tiket \\
& tetapi... \\
\hline
\end{tabular}

The auxiliary of 'can' in the sentence 'we don't can tiket' as in Indonesian 'kami tidak dapat tiket' above came from the structure of Indonesia.

\section{c) Adverb Phrase}

An adverb phrase consist of an adjective with $-\mathrm{ly}$. The interference of Indonesian occur on these following phrases.

(S1b) we eat direct kami langsung makan 
$\mathrm{S} 1 \mathrm{~b}$

\begin{tabular}{|c|c|}
\hline Incorrect & Correct \\
\hline we eat direct & we eat directly \\
\hline $\begin{array}{l}\text { kami langsung } \\
\text { makan }\end{array}$ & $\begin{array}{l}\text { kami langsung } \\
\text { makan }\end{array}$ \\
\hline
\end{tabular}

The phrases 'with happy' in the sentence 'we swim together with happy' is a form of Indonesian interference in the adverb phrase.

(S7b) we swim together with happy

kami berenang bersama dengan bahagia

$\mathrm{S} 7 \mathrm{~b}$

\begin{tabular}{|l|l|}
\hline \multicolumn{1}{|c|}{ Incorrect } & \multicolumn{1}{c|}{ Correct } \\
\hline we swim together & we swim together \\
with happy & happily \\
kami berenang & kami berenang \\
bersama dengan & bersama dengan \\
bahagia & bahagia \\
\hline
\end{tabular}

\section{d) Preposition Phrase}

A prepositional phrase consist of a preposition and noun phrase. These following prepositional phrases are carried out from the structure of Indonesian.

(S22a) My parent love me but only with love word no there proof

Orangtua saya mencintai saya tetapi hanya dengan kata cinta tidak ada bukti

\begin{tabular}{|c|c|c|}
\hline $2 \mathrm{a}$ & Incorrect & Correct \\
\hline & $\begin{array}{l}\text { My parent love } \\
\text { me but only with } \\
\text { love word no } \\
\text { there proof }\end{array}$ & $\begin{array}{l}\text { My parent love } \\
\text { me but only with } \\
\text { love word } \\
\text { without proof }\end{array}$ \\
\hline & Orangtua & Orangtua \\
\hline & $\begin{array}{l}\text { mencintai } \quad \text { saya } \\
\text { tetapi } \quad \text { hanya } \\
\text { dengan kata cinta } \\
\text { tidak ada.... }\end{array}$ & $\begin{array}{l}\text { mencintai } \quad \text { saya } \\
\text { tetapi } \quad \text { hanya } \\
\text { dengan kata cinta } \\
\text { tidak ada bukti }\end{array}$ \\
\hline
\end{tabular}

The phrase 'no there proof' or 'tidak ada bukti' in Indonesian is a prepositional phrase with preposition 'without' or 'tanpa' in Indonesian.

\section{Sentence}

\section{a) Verbal Sentence}

Verbal sentence is a sentence which predicate is a verb. Indonesian and English have sentences which consist of subject, verb, and complement. In order to retell past events or experience in English is used a past verb.
Past verb is divided into irregular and regular verb.

These following verbal sentences has an irregular verb of 'go' which carried out the sentence structure of Indonesian.

(S1a) Yesterday, I and my sister go to Genasi Hill

Kemarin, saya dan kakak saya pergi ke Bukit Genasi

\begin{tabular}{|c|c|}
\hline Incorrect & Correct \\
\hline $\begin{array}{l}\text { Yesterday, I and } \\
\text { my sister go to } \\
\text { Genasi Hill }\end{array}$ & $\begin{array}{l}\text { Yesterday, I and } \\
\text { my sister went to } \\
\text { Genasi Hill }\end{array}$ \\
\hline $\begin{array}{ll}\text { Kemarin, } & \text { saya } \\
\text { dan kakak saya } \\
\text { pergi ke Bukit } \\
\text { Genasi }\end{array}$ & $\begin{array}{lr}\text { Kemarin, } & \text { saya } \\
\text { dan kakak saya } \\
\text { pergi ke Bukit } \\
\text { Genasi }\end{array}$ \\
\hline
\end{tabular}

These following verbs are irregular verbs of 'come' found in the verbal sentences.

(S15c) Last Monday, I have problem because I come a school late Bulan lalu, saya punya masalah karena saya datang ke sekolah terlambat

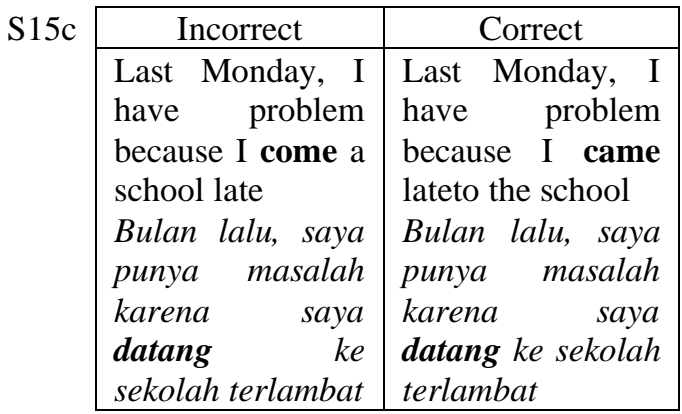

\section{b) Nominal Sentence}

Nominal sentence is a sentence which predicate are noun, adjective, and adverb. The sentences consist of subject, to be, and predicate. Unfortunatelly, there is not available to be in Indonesian sentence. Therefore these nominal sentences which carry out the structure from Indonesian omit the use of to be in the nominal sentence.

These following nominal sentences are improved by using to be 'was'.

(S4c) Four days ago I very happy because my favorit miss came in my school.

Empat hari yang lalu saya sangat 
senang karena guru favorit saya

datang di sekolah saya

$\mathrm{S} 4 \mathrm{c}$

\begin{tabular}{|c|c|}
\hline Incorrect & Correct \\
\hline Four days ago I & Four days ago I \\
\hline happy & was very happ \\
\hline because & because \\
\hline favorit miss came & favorit miss came \\
\hline in my school. & school \\
\hline Empat hari yang & Empat hari yang \\
\hline lalu saya sangat & lalu saya sangat \\
\hline guru favorit saya & guru favorit saya \\
\hline $\begin{array}{l}\text { datang di sekolah } \\
\text { saya }\end{array}$ & $\begin{array}{l}\text { datang di sekolah } \\
\text { saya }\end{array}$ \\
\hline & saye \\
\hline
\end{tabular}

These following nominal sentences are improved by using to be 'were' before the adjectives.

(S3a) We very happy

Kami sangat senang

S3a

\begin{tabular}{|c|c|}
\hline Incorrect & Correct \\
\hline We very happy & We were very \\
\hline $\begin{array}{l}\text { Kami } \quad \text { sangat } \\
\text { senang }\end{array}$ & $\begin{array}{l}\text { happy } \\
\text { Kami } \\
\text { senang }\end{array}$ \\
\hline
\end{tabular}

\section{c) Negative Sentence}

Negative sentence in Indonesian is indicated with 'tidak' as in 'dia tidak pergi' in verbal sentence and 'dia tidak senang' in nominal sentence. Moreover, English negative sentence is indicated with 'do not' or 'does not' in the verbal sentence and 'not' in the nominal sentence. The carrying out the structure of Indonesian into English also occur in the negative sentence as follow.

(S20a) I not intend...

Saya tidak berniat...

\begin{tabular}{|l|l|l|}
\hline \multicolumn{1}{|c|}{ S20a } & \multicolumn{2}{c|}{ Correct } \\
\cline { 2 - 3 } & $\begin{array}{l}\text { I not intend... } \\
\text { Saya } \quad \text { tidak } \\
\text { berniat... }\end{array}$ & I do not intend... \\
Saya & berniat... \\
\hline
\end{tabular}

\section{c. Semantic Interference}

This type of interference occur because of the changing of the certain words meaning. The interference of this type found in the recount text of students showed as following.

(S1c) ....and eat evening

...dan makan malam
S1c

\begin{tabular}{|c|c|}
\hline \multicolumn{1}{|c|}{ Incorrect } & Correct \\
\hline $\begin{array}{l}\text {...and eat } \\
\text { evening } \\
\text {..dan makan } \\
\text { malam }\end{array}$ & $\begin{array}{l}\text {....and dinner } \\
\text { malam }\end{array}$ \\
\hline
\end{tabular}

This 'eat evening' words are copied from Indonesian word meaning of 'makan malam'. The English words of 'eat evening' is 'dinner'

\section{DISCUSSION}

On how Indonesian interferes recount texts written by students of SMA Negeri 1 Toma fortunately is confirmed by Scotton (2005) that interference also refers to a number of other effects such as adopting the way sentences are structured. Students of SMA Negeri 1 Toma adopted the way of Indonesian words, phrases, and sentences are structured into the recount text written by them.

A relevant research is the one conducted by Khotimah (2009). She found the same result as this research result that:

Interferensi bidang leksikal meliputi penggunaan kata-kata dalam bahasa Jawa yang dimasukkan ke dalam kalimat bahasa Indonesia, walaupun sebenarnya kata-kata itu sudah ada padanannya.

The way on how interference occured according to her was by putting the words of Javanese into the sentences of Indonesian.

Moreover, the adopting of the way language is structured as stated in the two theories above is caused by the influencing of L1 and L2. This theory elaborated by Winford in Hickey (2010) that interference... described as the influence of an L1 or other primary language on an L2. Students of SMA Negeri 1 Toma adopted the way of Indonesian words, phrases, and sentences are structured because they do not master Indonesian or L2 as well while Cummins \& Davison (2007) stated that the $\mathrm{L} 3$ acquisition process is influenced not just by L1 (as in second language acquisition) but also by L2. Therefore most of the students of SMA Negeri 1 Toma are incapable of structuring Indonesian.

Discussing language mastery as one of the influences of languages, Gulö (2014) confirmed that depending on the mastery level or how good the speakers at Bahasa Indonesia, one might find more or less kinds of linguistic influences that appear. 
Besides, a study conducted on Indonesian language interference towards English in the writing of scientific journal article (Budiarti, 2013), supports the finding of the present research. of Any Budiarti entitled "Interferensi Bahasa Indonesia ke dalam Bahasa Inggris pada Abstrak Jurnal Ilmiah" has a similar finding with this study. In Any's finding, types of Indonesian interference consist of morphological interference, syntactical interference, and semantic interference.

In addition, the types in this research are including in the types of interference studied by Chaer \& Agustina (2010) that types of interference are distinguished into phonology, morphology, and syntactical.

In conclusion, the way of how Indonesian interfered recount text written by students of SMA Negeri 1 Toma was by adopting the way of Indonesian words, phrases and sentences are structured.

\section{CONCLUSION}

After studying the data it can be concluded that Indonesian interferes the recount texts written by students of SMA Negeri 1 Toma throguh the students adopting the way of Indonesian words, phrases, and sentences are structured. Moreover morphological, syntactical and semantic interference were the types of Indonesian interference in recount text written by students of SMA Negeri 1 Toma. Most of the students of SMA Negeri 1 Toma do not master Indonesian or L2 and English or L3 therefore they adopted the way of Indonesian words, phrases, and sentences are structured into the recount text. The interference most occur in structuring the phrases and sentences in the recount texts.

\section{REFERENCES}

Agustia, K. T. S. (2018). Indonesian Interference on English Language in VIII Grade Junior High School Students. Global Conference on Teaching, Assessment, and Learning in Education (GC-TALE 2017), 42, 1-6.

Baker, P., \& Ellece, S. (2011). Key Terms in Discourse Analysis. Continuum International Pub. Group.

Brown, L. (2001). A grammar of Nias Selatan [University of Sydney].

Budiarti, A. (2013). Interferensi Bahasa Indonesia ke dalam Bahasa Inggris pada Abstrak Jurnal Ilmiah. Jurnal Bahasa, Sastra, Seni, Dan Pengajarannya, 41(1), 10-17.
Budiharto, R. A. (2019). Native Language Interference on Target Language Writings of Indonesian Efl Students: an Exploratory Case Study. Indonesian EFL Journal, 5(1), 107116.

Chaer, A., \& Agustina, L. (2010). Sosiolinguistik: Perkenalan Awal. Rineka Cipta.

Cummins, J., \& Davison, C. (2007). International Handbook of English Language Teaching. Springer US.

Djuanda, D. (2018). Language Interferences in Social Media. International Conference on Business, Economic, Social Sciences and Humanities (ICOBEST 2018), 225, 240-243.

Gulö, I. (2014). The Influence of Nias Language to Bahasa Indonesia. Konferensi Linguistik Tahunan Atma Jaya, 231-234.

Hickey, R. (2010). The Handbook of Language Contact. Wiley-Publisher.

Iman, T. R. (2020). The Interference of Indonesian on English Second Language Writing. Journal of Languages and Language Teaching, 8(2), 170-182.

Khotimah, K. (2009). Interferensi Bahasa Jawa ke dalam Bahasa Indonesia pada Karangan Narasi Siswa Kelas I MTS Yasin Nglangak, Kwangen, Gemolong, Sragen [Universitas Muhammadiyah Surakarta].

Miles, M., M., H. A., \& Saldana, J. (2014). Qualitative Data Analysis: A Methods Sourcebook (3rd ed.). Sage Publisher.

Scotton, C. M. (2005). Multiple Voices: An Introduction to Bilingualism. Blackwell Publishing.

Swan, M., \& Smith, B. (2001). Learner English: A Teacher's Guide to Interference and other Problems (2nd ed.). Cambridge University Press.

Syarif, H. (2014). Factors Causing Indonesian Grammatical Interferences on English Use: A Case of Undergraduate Students ' Expository Writing in Padang, Indonesia. In W. Sartika (Ed.), Language Awareness on TEFL for Multigulingual Learners (pp. 189-195). Universitas Negeri Padang Repository.

Tarukallo, Y., \& Usman, F. R. and S. (2017). Syntactic Interference in Translating Indonesian Narative Text into English for The Students of English Education Study Program at Tentena Christian University. Bahasantodea, 5(2), 43-53. 